\title{
CORRIGENDA
}

\section{Gene therapy of liver tumors with human liver-specific nanoparticles}

\section{Ueda, Y Iwasaki, T Yamada, A Kondo, M Seno, K Tanizawa, S Kuroda, M Sakamoto and M Kitajima}

Cancer Gene Therapy (2007) 14, 440. doi: 10.1038/sj.cgt.7701031

Correction to: Cancer Gene Therapy (2007) 14, 74-81. doi: 10.1038/sj.cgt.7700990

Since the publication of the above article, the authors have identified an error in the title of Figure 4d. The correct title is WiDr: PBS, is shown below. The authors would like to apologize for this mistake.

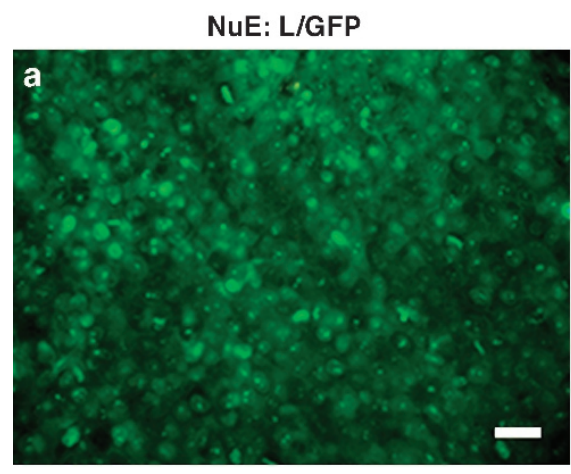

NuE: PBS

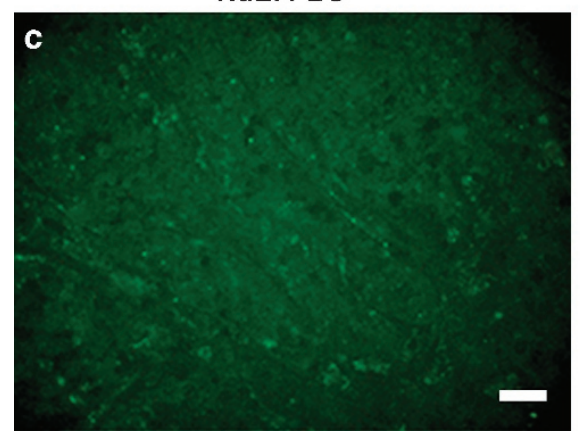

WiDr: L/GFP

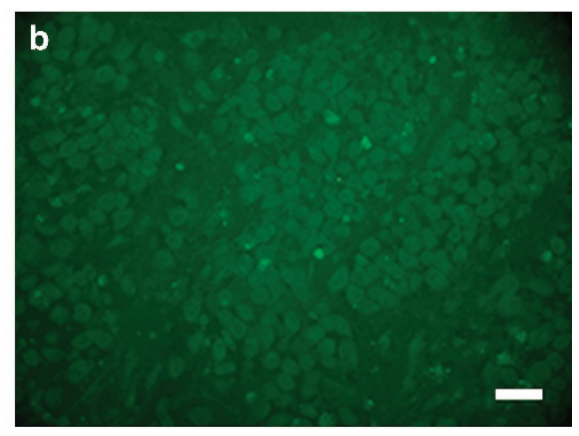

WiDr: PBS

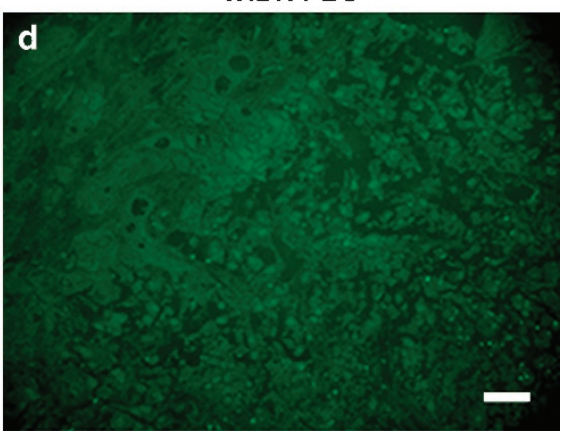

\section{A gene transfer comparative study of HSA-conjugated antiangiogenic factors in a transgenic mouse model of metastatic ocular cancer \\ E Frau, C Magnon, P Opolon, E Connault, D Opolon, F Beermann, M Abitbol, $M$ Perricaudet and $C$ Bouquet \\ Cancer Gene Therapy (2007) 14, 440. doi: 10.1038/sj.cgt.7701032}

Correction to: Cancer Gene Therapy (2007) 14, 251-261. doi: 10.1038/sj.cgt.7701005

The author name F Beermann was published incorrectly in the above article. The correct author list is now shown. 